\title{
Living with a College Roommate in a Residence Hall ${ }^{1}$
}

\section{Suzanna Smith and Heather Wallace ${ }^{2}$}

As you enter college, you may wonder what it will be like to live in a residence hall and share a space with a roommate. Dorm life can be exciting and a little scary, too. A good roommate relationship is important-it can help you navigate many of the changes you are about to make. A good relationship can enrich campus life by fostering a sense of belonging. A good roommate relationship can also benefit your academic work, including class attendance, GPA, and test scores. Having a positive relationship with your roommate can even improve overall mental health.

\section{Steps to Consider}

What are a few steps you can take to help establish a good relationship between you and your roommate?

1. Keep the lines of communication open. You are sharing small living quarters and spending time around each other during the day and night. Some differences and disagreements about daily life (e.g., noise levels, visitors, quiet hours, and living habits) are normal. It is important to be able and willing to talk about differences and solve problems as they arise. It might help to think about this as a partnership where you are working together. State your views and preferences clearly and without criticizing your roommate. Be willing to listen, be supportive, and talk about things in respectful ways. You can also take advantage of communication and roommate skills workshops offered on campus and in your residence hall.
2. Talk about daily habits from the beginning. You and your roommate have, for years, taken care of yourselves and managed your own lives. Both of you probably have your own preferences and habits. From the beginning, talk about your ways of doing things and preferences. Be flexible and willing to talk about things again if you feel uncomfortable about something. Here are a few key boundaries that roommates often have to work out:

- Waking and sleeping times around class, study, and work schedules

- Study spots and the quiet you need (or noise tolerance you have)

- Bathroom needs, belongings, and cleanliness (if you share a bathroom)

- Overall neatness and cleanliness (i.e., food storage, eating in the room, cleaning up, washing dishes, keeping personal space tidy, taking out the trash, and cleaning the fridge)

- Designated areas for personal belongings, and shared items such as food, supplies, and clothing (Label your things.)

- Socializing in the room, including inviting guests unannounced, having people stay over, throwing parties, smoking, and drinking

\section{Know what you expect and want from a roommate} experience. Do you want to be best friends and explore college life together or would you rather go your own

1. This document is FCS3349, one of a series of the Department of Family, Youth and Community Sciences, UF/IFAS Extension. Original publication date February 2019. Visit the EDIS website at https://edis.ifas.ufl.edu for the currently supported version of this publication.

2. Suzanna Smith, CFLE, associate professor, Department of Family, Youth and Community Sciences; and Heather Wallace, CFLE, assistant professor, human development specialist, Family and Consumer Sciences, University of Tennessee; UF/IFAS Extension, Gainesville, FL 32611.

The Institute of Food and Agricultural Sciences (IFAS) is an Equal Opportunity Institution authorized to provide research, educational information and other services only to individuals and institutions that function with non-discrimination with respect to race, creed, color, religion, age, disability, sex, sexual orientation, marital status, national origin, political opinions or affiliations. For more information on obtaining other UF/IFAS Extension publications, contact your county's UF/IFAS Extension office. 
way? Do you expect your roommate to share their thoughts and feelings or would you prefer privacy? Big differences in what you want may affect the quality of the relationship. Nevertheless, you can still be compatible and live well together. Recognize that people are different and be supportive of each other. You may need to talk about your differences and look to others for friendship if you want more closeness.

\section{Make sure that both of you can sleep. Getting enough} sleep is important to your health, stress level, and academic performance. Discuss your preferred schedules for quiet time and sleep so both of you can get the rest you need. Take steps to reduce disturbances from noise and light in the room by using earplugs and a sleep mask. Power down electronics an hour or two before bed and use an app that filters the blue light exposure that disrupts sleep. Practice good sleep habits by avoiding exercise near bedtime, eliminating caffeine intake later in the day, and practicing relaxation techniques such as meditation or yoga before bed.

5. Take care of yourself! Adjusting to college and living away from home with someone you don't know can be stressful! Self-care goes a long way towards helping you manage stress and enjoy your new life. Self-care includes:

- keeping a positive outlook on things;

- making relaxation and other stress reduction techniques a part of your daily life;

- confiding in someone you trust;

- getting away from the dorm from time to time to do something outside or with friends

- maintaining your health through regular exercise, healthy eating, germ control, and adequate sleep; and

- monitoring and maintaining your mental health and getting the help you need from your residence hall advisor, a counselor, a health care provider, or an advisor.

6. Communicate with your Resident Assistant. Your RA is an important resource! They can offer support as you get used to dorm and campus life and suggest other helpful resources. They can answer questions about academics and social life and give advice and assistance with roommate tensions or issues. If needed, your RA can mediate with roommates or help you find a different environment on campus that will still help you succeed as a student. Contact your Resident Assistant if you need help with your living situation or environment.

\section{Conclusion}

Your relationship with your roommate is an important part of college life. This relationship requires ongoing attention to stay healthy and positive. Good communication skills, willingness to work together to solve problems, and an understanding of each other's needs all pave the way for a positive relationship.

\section{References}

Erb, S. E., Renshaw, K. D., Short, J. L., \& Pollard, J. W. (2014). The importance of college roommate relationships: A review and systemic conceptualization. Journal of Student Affairs Research and Practice, 51(1), 43-55. http://dx.doi. org/10.1515/jsarp-2014-0004

Gilbert, N. (2016). 10 tips for living with a college roommate. Forbes. Retrieved from https://www.forbes.com/sites/ noodleeducation/2016/08/22/10-tips-for-living-with-acollege-roommate/\#2524da073bce

Hanasono, L. K. \& Nadler, L. B. (2012). A dialectical approach to rethinking roommate relationships. Journal of College Student Development, 53(5), 623-635. https://doi. org/10.1353/csd.2012.0069

Langlois, M. K. (2018). The stresses of dorm life. Reporter [Rochester Institute of Technology]. Retrieved from https:// reporter.rit.edu/features/stresses-dorm-life

Sexton-Radek, K. \& Hartley, A. (2013). College residential sleep environment. Psychological Reports: Mental and Physical Health, 113, 903-907.

Tarun, J. \& Kapoor, M. (2015). The impact of study groups and roommates on academic performance. The Review of Economics and Statistics, 97(1), 44-54. doi:10.1162/ REST_a_00454

Urist, J. (2013). The health risks of small apartments. The Atlantic. Retrieved from https:// www.theatlantic.com/health/archive/2013/12/ the-health-risks-of-small-apartments/282150/ 